\title{
Heavy metals pollution of two hyper-saline lagoons, Lake Malaha East Port-Said, Egypt
}

\author{
Mokhtar S. Beheary ${ }^{1}$, Yasser M. Sultan ${ }^{1}$, Elsayed A. Zaghloul ${ }^{2}$, Mariam H. Sheta*1 \\ ${ }^{1}$ Faculty of Science, Port-Said University, Egypt. \\ ${ }^{2}$ National Authority for Remote Sensing and Space Sciences, Cairo, Egypt.
}

Received: 12 February 2015/ December Accepted: 202016

*Corresponding author: mariamsheta306@yahoo.com

\begin{abstract}
Heavy metals pollution is common problem in many lakes of Egypt, so this research aimed to assess this problem in Lake Malaha. Twenty-four samples taken from water and sediments of the lagoons of Lake Malaha. The water samples were collected and preserved by storing in acid-washed polyethylene bottles, sediment samples were collected and then kept in cleaned plastic bags and chilled on ice box. The chemical analysis for either water samples or sediment samples was assessed. The measured metals were $\mathrm{Cr}, \mathrm{Fe}, \mathrm{Cd}$, and $\mathrm{Zn}, \mathrm{Ba}$ and $\mathrm{Pb}$. The obtained results showed that all concentrations of the measured heavy metals were within the permissible limits, this motivates us to maintain the lake and manage it in a good environmental manner and this will be a benefit for increasing fisheries and maintain biodiversity.
\end{abstract}

Keywords: Heavy metals, Pollution, Lake, Water, Sediment, Mediterranean, Sinai.

\section{Introduction}

Heavy metals in the aquatic environment are usually monitored by measured concentrations in water, sediments and biota. Determination of heavy metals concentrations in surface water samples is difficult because of the concentrations is low, also display wide fluctuation (Mastala et al., 1992). The contamination by heavy metals in the aquatic environments has drawn particular attentions due to their toxicity, persistence and biological accumulation (Zahran et al., 2015). In aquatic systems, heavy metals have received considerable attention due to their toxicity and accumulation in biota (Mason, 1991). The most anthropogenic sources of metals are industrial, petroleum contamination and sewage disposal (Liaghati et al., 2003). The impact of such heavy metals abnormality may extend to involve the water quality and food web, and hence to the human health (El-Badry, 2016). Some of these metals, such as $\mathrm{Cd}$ and $\mathrm{Pb}$, are toxic to living organisms even at quite low concentrations, whereas others, such as $\mathrm{Zn}$ and $\mathrm{Cu}$, are biologically essential and natural constituents of aquatic ecosystems, 
and generally only become toxic at very high concentrations. $\mathrm{Zn}$ has a multitude of biological functions in the human body. It is an important constituent of over 100 enzymes involved in a variety of fundamental metabolic processes. It is involved in the production and function of several hormones. Excessive intake of $\mathrm{Zn}$ causes abdominal pain, violent vomiting, collapse, and degenerative changes in the liver. $\mathrm{Cd}$ is considered the most toxic element to human life. It causes itai-itai, a bone disease similar to rickets, and cardiac enlargement, anemia, gonadal atrophy, kidney failure and pulmonary emphysema. $\mathrm{Pb}$ is toxic and a major hazard to man and animals. Poisoning by lead causes anemia, encephalopathy, weight and coordination loss, abdominal pain, vomiting, constipation, and insomnia (Khallaf et al., 1998). chromium (Cr) which is its sources entering the aquatic environment from paint and chemical works, oil drilling and recovery rigs, large quantities of chromium may be released from petrochemical industries and cement, fertilizer, power, and chlor-alkali plants (Zahran et al., 2015). Iron is the second most abundant metal and fourth most abundant element in the Earth's crust (Taylor, 1964), but its concentration in water is quite low because of low solubility (Molot and Dillon, 2003). Barium is Toxic; used in rat poison. In moderate to large concentrations can cause death; smaller concentrations cause damage to the heart, blood vessels, and nerves (EPA, 1994a). Sediment quality is a good indicator of pollution in water column, where it tends to concentrate the heavy metals and other organic pollutants (Saeed and Shaker, 2008). There are high quantities of heavy metal pollution of lakes in Egypt such this pollution that (Fe, Mn, $\mathrm{Cd}$ and $\mathrm{Pb}$ in Lake Manzala) and (Mn and $\mathrm{Pb}$ in Lake Borollus) recorded levels above the international permissible limits in water. In sediment samples (Mn in Lake Edku) and (Cd in Lake Manzala) recorded higher values than the sediment quality guidelines (Saeed and Shaker, 2008). Manzala Lake is highly contaminated with $\mathrm{Fe}, \mathrm{Cd}, \mathrm{Pb}$ and $\mathrm{Cr}$ due to the continuous discharge of different pollutants into it. It can also be concluded that the southern drains namely, Bahr El-Baqar, Ramsis, ElMatria, Hadous, Faraskur, El-Serw and
Lissa El-Gamalia play an important role in causing a severe pollution in Manzala Lake (Zahran et al., 2015).

The main objective of this study is to assess heavy metals pollution in the two hypersaline lagoons of Lake Malaha through determining the accumulation of $\mathrm{Cr}, \mathrm{Fe}$, $\mathrm{Cd}$, and $\mathrm{Zn}, \mathrm{Ba}$ and $\mathrm{Pb}$ in water and sediments of those lagoons, this obtained results will be useful for credible management of the two lagoons.

\section{Martials and Methods}

\subsection{Study area}

Lake Malaha lies in the northwestern corner of El-Tina plain, east of Port Fouad city and directly east of the Suez Canal between Longitudes: $32^{\circ} 21^{\prime} 30^{\prime \prime} \& 32^{\circ} 30^{\prime}$ $\mathrm{E}$ and Latitudes: $31^{\circ} 77^{\circ} \& 31^{\circ} 13^{`} \mathrm{~N}$ (Fig. 1). Lake Malaha has a triangular shape and connected with the Mediterranean Sea by a small inlet near Port-Fouad and other shallow tidal inlets. The surface area decreased from 33,000 to 21,000 feddans after 1976 conflict, as the result of the construction of a road between Rommana and kilometer 19th on the Suez Canal. Lake Malaha consists of two shallow hypersaline lagoons, the size and shape of which are variable; they reach the maximum size during winter and become nearly dry in summer season. The lagoons are connected to the Mediterranean Sea via Boughaze ElKalaa (Eastern lagoon) and Boughaze ElMalaha (Western lagoon). The two lagoons are separated from the Mediterranean Sea by a sandbar that varies in width between 100 to 500 m (Ahmed and El-Mor, 2006). There is no freshwater influx in the lake (Hanafy et al., 1996).

Lake Malaha is one of the most important water bodies along the northern coast of Egypt for its fisheries resources. It represents an important rout for migratory birds. The present area of Lake Malaha is $11.43 \mathrm{~km} 2$ while it was $19.86 \mathrm{~km} 2$ in 2005 , this is because of the changes and expansions carried out in east Port Said area. Also as a result of these expansions and projects in this area, the western area of the lake is bridged. 

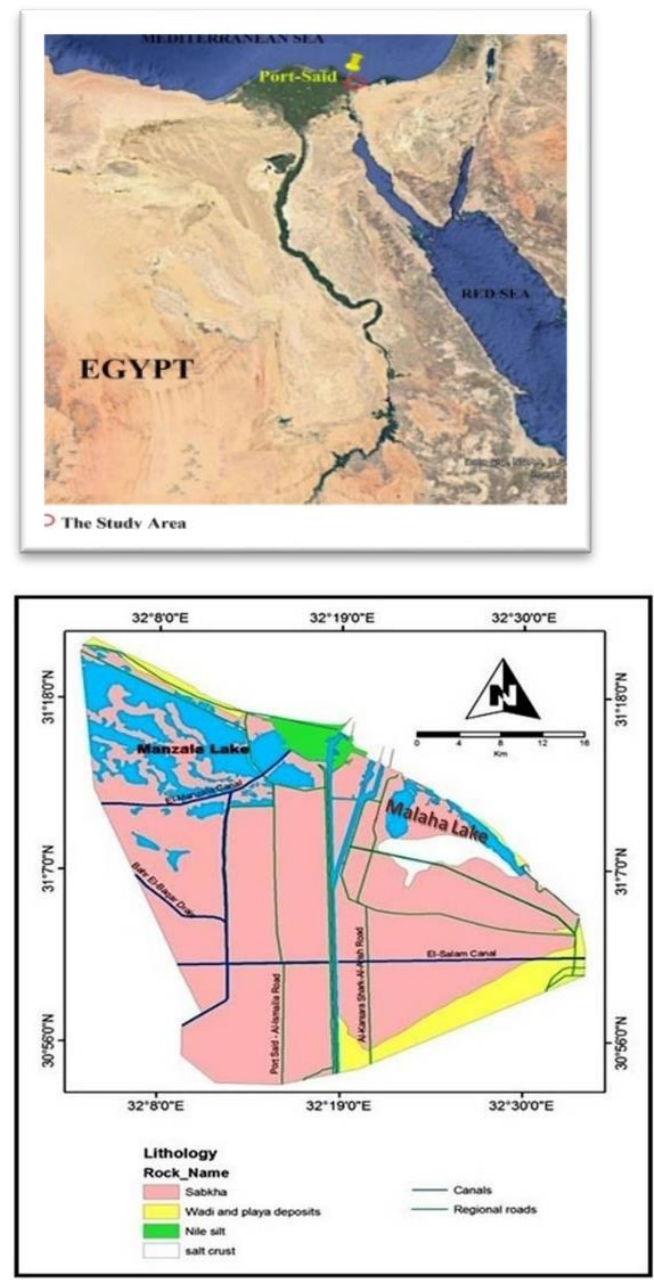

Fig.(1): Location map of Lake Malaha

\subsection{Sampling and analysis: -}

Sampling occurred in two lagoons of the lake, the western lagoon and eastern lagoon as showed in (Fig. 2).

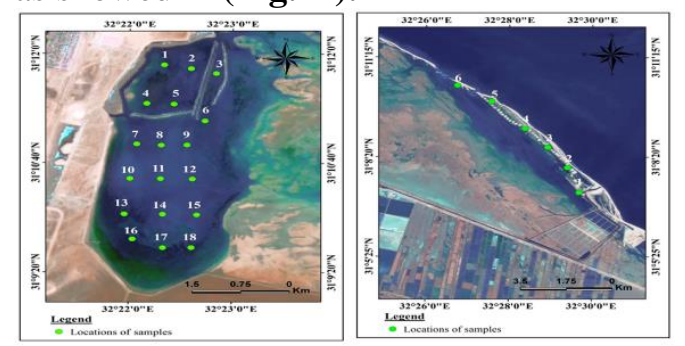

Fig. (2): Sampling in the two lagoons (western and eastern) of Lake Malaha

\subsubsection{Sampling and analysis of water: -}

In October 2015, 18 water samples were taken from different stations covered the western lagoon completely. Geographic positions of these samples were appointed using the GPS device. In October 2016, six water samples were taken from different stations in the eastern lagoon. Sampling was carried out according to the standard methods for examination of water and wastewater (APHA, 2005). Water samples were collected and then stored in acidwashed polyethylene bottles for heavy metals analyses. The water analyses for heavy metals were carried out in the laboratories of the Chemical Warfare Management, Armored Forces for detecting the heavy metals; $\mathrm{Cr}, \mathrm{Fe}, \mathrm{Cd}, \mathrm{Zn}$, $\mathrm{Ba}$ and $\mathrm{Pb}$. The analyses procedures are carried out according to the laboratory schemes after preparing the collected samples. Samples were being filtered using filtration system through $0.45 \mu \mathrm{m}$-porediameter filter paper then analyzed for trace elements using Inductively Coupled Plasma-Optical Emission Spectroscopy (ICP-OES) with ultrasonic nebulizer (USN), this Nebulizer decrease the instrumental detection limits by $10 \%$, this ICP instrument is Perkin Elmer Optima 3000, USA (APHA, 2005).

\subsubsection{Sampling and analysis of sediments:}

Eighteen sediment samples were collected at the same stations of the water samples in the western lagoon using core sampler. Six sediments samples were collected from the sediments at the same stations of the water samples in the eastern lagoon using hand, then kept in cleaned plastic bags and chilled on ice box for transport to the laboratories of the Chemical Warfare Management, Armored Forces, for heavy metals analysis. The samples were air dried at room temperature $\left(25^{\circ} \mathrm{C} \pm 2\right)$, crushed and finely grounded, sieved through $(0.2 \mathrm{~mm})$ sieve and kept for heavy metals analysis according to (APHA, 2005), The heavy metals measured were that $\mathrm{Cr}, \mathrm{Fe}, \mathrm{Cd}, \mathrm{Zn}, \mathrm{Ba}$ and $\mathrm{Pb}$.

\section{Results and discussion: -}

\subsection{Heavy metals in water samples: -}

As showed in (Table 1) the average of chromium concentration in the western lagoon is $0.006 \mathrm{mg} / \mathrm{l}$, while in the eastern lagoon is 0.001 . The maximum contaminant level of $\mathrm{Cr}$ is $0.1 \mathrm{mg} / \mathrm{l}$ (EPA, 1994a), which is meant the concentration of 
$\mathrm{Cr}$ is within the permissible limits. The average of Iron $(\mathrm{Fe})$ in the western lagoon as showed in (Table 1) is $0.084 \mathrm{mg} / \mathrm{l}$, while in the eastern lagoon is $0.014 \mathrm{mg} / \mathrm{l}$. The permissible limit of $\mathrm{Fe}$ is $1 \mathrm{mg} / \mathrm{l}$ (USEPA, 1986) that meant the concentration of $F e$ is within the permissible limits. The average of cadmium concentration in the western lagoon is $0.003 \mathrm{mg} / \mathrm{l}$ while in the eastern lagoon is less than $0.001 \mathrm{mg} / \mathrm{l}$ as illustrated in (Table 1). The maximum contaminant level of $\mathrm{Cd}$ is $0.005 \mathrm{mg} / \mathrm{l}(\mathbf{E P A}, \mathbf{1 9 9 4 a})$ that meant that the concentration of $\mathrm{Cd}$ in the two lagoons is within these limits. There is no detectable zinc concentration in the western lagoon while in the eastern lagoon the average concentration of $\mathrm{Zn}$ is less than

Table (1): Concentration of heavy metals in water samples in the two lagoons of Lake Malaha

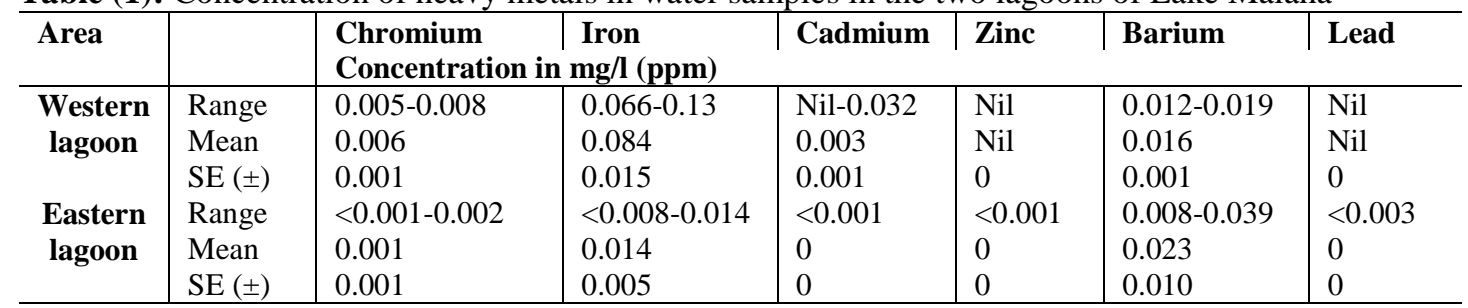

\subsection{Heavy metals in sediment samples: -}

For the western lagoon, the average of $\mathrm{Cr}$ concentration is $0.001 \mathrm{ppm}$ while in the eastern lagoon is $0.074 \mathrm{ppm}$ as showed in (Table 2). The maximum permissible limit of $\mathrm{Cr}$ in sediment is $0.5 \mathrm{ppm}$ (KabataPendias, 1995); this meant that cadmium concentration is within that limit. The average of $\mathrm{Fe}$ concentration in the western lagoon is $0.008 \mathrm{ppm}$ while in the eastern lagoon is $6.98 \mathrm{ppm}$ a showed in (Table 2). The permissible limit of $\mathrm{Fe}$ in sediments is 20 ppm (DPR, 2002 and FEPA, 2003); this meant that $\mathrm{Fe}$ concentration in the two lagoons is within that limit. As showed in (Table 2) the average concentration of $\mathrm{Cd}$ in the western lagoon is less than $0.001 \mathrm{ppm}$ while in the eastern lagoon is $0.001 \mathrm{ppm}$. The maximum permissible limit of $\mathrm{Cd}$ in

Table (2): Concentrations of heavy metals in sediment samples of the two lagoons of Lake Malaha

\begin{tabular}{c|l|l|l|l|l|l|l|l}
\hline \multicolumn{1}{c}{ Area } & & Chromium & \multicolumn{2}{|c|}{ Iron } & $\begin{array}{c}\text { Cadmium } \\
\text { Concentration in }(\mathbf{p p m})\end{array}$ \\
& Western & Range & $0.001-0.002$ & $0.008-0.009$ & $<0.001$ & $<0.001$ & $0.008-0.039$ & $<0.003$ \\
lagoon & Mean & 0.001 & 0.009 & 0 & 0 & 0.023 & 0 \\
& SE $( \pm)$ & 0.0005 & 0.0008 & 0 & 0 & 0.0124 & 0 \\
Eastern & Range & 0.046 & 3.512 & 0.001 & 0.118 & 0.017 & 0.015 \\
lagoon & Mean & 0.074 & 6.98 & 0.001 & 0.190 & 0.040 & 0.028 \\
& SE $( \pm)$ & 0.036 & 3.264 & 0.0005 & 0.074 & 0.028 & 0.015 \\
\hline
\end{tabular}

$0.001 \mathrm{mg} / \mathrm{l}$ as showed in (Table 1). The permissible limit of $\mathrm{Zn}$ is $1 \mathrm{mg} / \mathrm{l}$ (USEPA, 1986); that meant the concentration of $\mathrm{Zn}$ in the two lagoons is within that limit. The average of barium concentration in the western lagoon is $0.016 \mathrm{mg} / \mathrm{l}$ while in the eastern is $0.023 \mathrm{mg} / \mathrm{l}$ as showed in (Table 1). The maximum contaminant level of $\mathrm{Ba}$ is $2 \mathrm{mg} / \mathrm{l}$ (EPA, 1994a) that meant that the concentration of $\mathrm{Ba}$ is within this limit. As showed in (Table 1) in the western lagoon, there isn't detectable lead concentrations while in the eastern lagoon is less than $0.003 \mathrm{mg} / \mathrm{l}$. The permissible limit of $\mathrm{Pb}$ is $0.05 \mathrm{mg} / \mathrm{l}$ (USEPA, 1986) that meant the concentration of $\mathrm{Pb}$ is within that limit. 
The present study shows that the quality degree of Lake Malaha environment is good and suitable for the growth of fish and aquatic organisms and also the lake is a suitable habitat for migratory birds. The two lagoons of the lake have good habitat and environment because the concentration of analyzed heavy metals rather in water or sediments is within the standards and permissible limits.

\section{Conclusion:}

Lake Malaha is one of the most important water bodies along the northern coast of Egypt for its fisheries resources. It represents an important rout for migratory birds. It consists of two hyper-saline lagoons, Western lagoon and Eastern lagoon. At the present time, the western lagoon is disappeared because of the projects and expansions at the eastern Port Said area. In this search an assessment of these two lagoons was performed through analysis of heavy metals for water and sediment. These heavy metals were $\mathrm{Cr}, \mathrm{Fe}$, $\mathrm{Cd}, \mathrm{Zn}, \mathrm{Ba}$ and $\mathrm{Pb}$. Through the analysis, it was showed that Lake Malaha has a good environment and habitat, also it is suitable for the growth of fish and aquatic organisms, a fit habitat for migratory birds and it is a resource for fisheries and increasing the national income, so we recommended that a lot of interest is given for the remnant lagoon (the eastern one) and great efforts and cooperation between different authorities are needed to protect the lake from any pollution, conserve and maintain it.

\section{References}

Ahmed, A.I. and El-Mor, M.E. (2006): Fisheries and The by-catch of the shrimp beach Seine in EL-Malaha Lake, Port- Said, Egypt. Egypt. J. Aquat. Biol. \& Fish., Vol. 10, No.4:65 - 83 .

American Public Health Association (APHA) (2005): Standard methods for the examination of water and wastewater. $21^{\text {st }}$ Ed., Washington D.C.

DPR, (2002): Environmental Guidelines and Standards for the Petroleum Industry in
Nigeria (EGASPIN), Department of Petroleum Resources, Nigeria.

El-Badry, A.A. (2016): Distribution of heavy metals in contaminated water and bottom deposits of Manzala Lake, Egypt. Journal of Environmental \& Analytical Toxicology. ISSN: 2161-0525.

FEPA (Federal Environmental Protection Agency) (2003): Guidelines and Standards for Environmental Pollution Control in Nigeria, Lagos, Nigeria.

Hanafy, M.H., Gab-Allah, A.A., Kotob, M.M., Ahmed A.I. and Amer, M.A. (1996): Report on environmental description and ecological imortance of the coastal region between Port Said and Tina Bay.

Kabata-Pendias, A. (1995): Agricultural problems related to excessive trace metals content of soil. In: Heavy metals (problem and solutions). Salomons W, Förstner U, Mader P (Eds.) Springer-Verlag, Berlin, Heidelberg, New York, London, Tokyo. pp: 3-18.

Khallaf, E.A., Galal, M. and Authman, M. (1998): Assessment of heavy metals pollution and their effect on Oreochromis nioticus in aquatic drainage canals. J Egypt Ger Soc Zoo 28(B):39-74.

Liaghati, T., Preda, M. and Cox, M. (2003): Heavy Metal Distribution and Controlling Factors within Coastal Plain Sediments, Bells Creek Catchments, Southeast Queensland, Australia. Environment International, 29, 935-948.

Mason, C. (1991): Biology of freshwater pollution. Longman Scientific and Technical, Harlow, England.

Mastala, Z.V., Balogh, K. and Salanki, J. (1992): Reliability of heavy metal pollution monitoring Utilizing aquatic animals' versus statistical evaluation methods. Arch. Environ. Contam. Toxicol, 23: 476 - 483.

Molot, L.A. and Dillon, P.J. (2003): Variation in iron, aluminum and dissolved organic carbon mass transfer coefficients in lakes. Water Research, 37, 1759-1768.

Persaud, D., Jaagumagi, R. and Hayton, A. (1993): The provincial sediment quality guidelines. Ontario Ministry of the Environment.

SAEED, S.M. and SHAKER, I.M. (2008): Assessment of heavy metals pollution in water and sediments and their effect on Oreochromis niloticus in the northern delta lakes, Egypt. 8th International Symposium on Tilapia in Aquaculture.

Summary of EPA finalized National primary drinking water regulations (1994a): U.S. 
Environmental Protection Agency Region VIII, $7 \mathrm{p}$.

Taylor, S.R. (1964): Abundance of chemical elements in the continental crust: a new table. Geochimica et Cosmochimica Acta, 28, 1273-1285.

United States Environmental Protection agency (USEPA) (1986): Quality Criteria for Water. EPA 440/5-86-001. Office of water regulations and standards. Washington DC., USA.

Zahran, M.A.E., El-Amier, Y.A., Elnaggar, A.A., Mohamed, H.A.E. and El-Alfy, M.A. (2015): Assessment and Distribution of Heavy Metals Pollutants in Manzala Lake, Egypt. Journal of Geoscience and Environment Protection. 3, 107-122.

\title{
الملخص العربي
}

\author{
عنوان البحث: التلوث بالعناصر الثقيلة فى بحيرتين شديدتين الملوحة لبحيرة الملاحة شرق بورسعيد ، مصر \\ مختار سامي بحيرى1 ، ياسر سلطان ، ، السيا زغلول22 ، مريم شتا1 \\ 1 قسم علوم البيئه - كلية العلوم - جامعة بورسعيد \\ 2 الهيئة القومية علوم الفضاء والأستشعار من بعد- القاهرة
}

تعتبر بحيرة الملاحة من الهم المسطحات المائية علي الساحل الثمالي لمصر كمصدر من مصادر الثروة

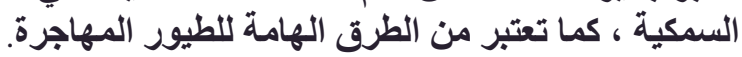

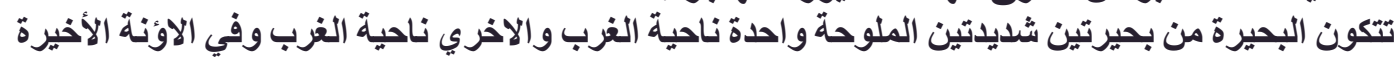

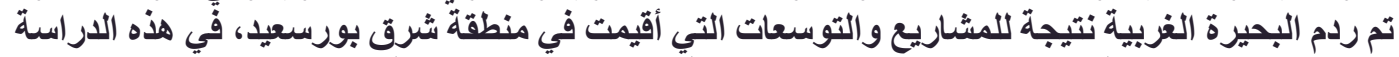

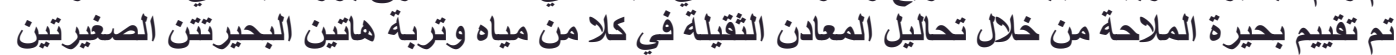

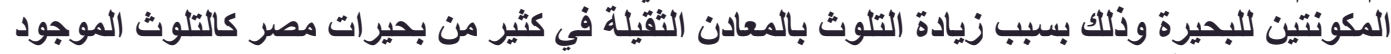

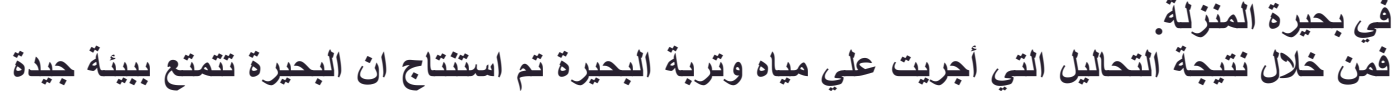

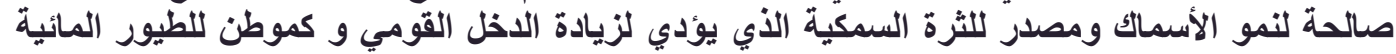

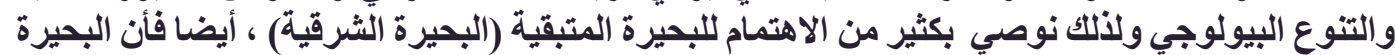

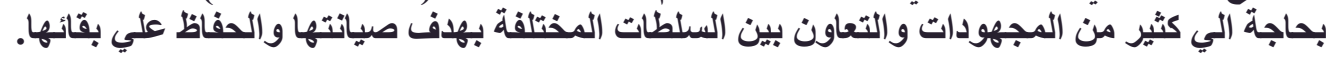

